\title{
Incidence of renal stones among cadmium exposed
} battery workers

\author{
Lars Järup, Carl Gustaf Elinder
}

\begin{abstract}
The health effects of occupational exposure to cadmium were studied in a group of 902 workers employed for at least one year in a Swedish battery factory between 1931 and 1982. Data on air cadmium concentrations for different periods were combined with company employment records to obtain individual cumulative exposure estimates. A questionnaire including questions on the occurrence of kidney stones was sent to all 601 living workers and to the next of kin of 267 of the deceased workers. The response rate was $88 \%$. 73 workers reported renal calculi that appeared after initial employment. A dose-response relation was found between cumulative exposure to cadmium and age standardised cumulative incidence. Incidence rate ratios (IRRs) were then computed for three exposure categories $\left(<250,250-<5000\right.$, and $5000 \mu \mathrm{g} / \mathrm{m}^{3} \times$ years) standardised for calendar time, age, and smoking with the low exposure group as reference level. The IRRs were 1.0, 1.6 [95\% confidence interval $(95 \% \mathrm{CI}) 0.7-3.4]$, and $3.0(95 \%$ CI 1-3-6.8) respectively. $\beta_{2}$ Microglobulin measurements were available for 33 workers who formed stones; 13 of these workers had tubular proteinuria $\left(\beta_{2}\right.$ microglobulin $\geqslant 34 \mu \mathrm{g} / \mathrm{mmole}$ creatinine)-that is, a prevalence of $39 \%$. There was also an indication of a steeper doseresponse relation among workers with tubular proteinuria.
\end{abstract}

(British Fournal of Industrial Medicine 1993;50:598-602)

It is well known that occupational exposure to cadmium can cause kidney damage, first noticed by an increased urinary excretion of low molecular weight proteins such as $\beta_{2}$ microglobulin. ${ }^{1}$ The clinical

Department of Occupational Medicine, Karolinska Hospital, Department of Hygiene and Department of Environmental Medicine, Karolinska Institute L Järup

Department of Occupational Medicine, Karolinska Hospital and Department of Renal Medicine, Huddinge University Hospital, Sweden C G Elinder significance of this early renal dysfunction is, however, unclear. The kidney damage may progress to glomerular impairment, ${ }^{2-6}$ eventually leading to uraemia and death in extreme cases. A few investigators have also reported an increased prevalence of renal calculi among workers exposed to cadmium,,$^{7-9}$ but a dose-response relation has so far not been shown.

Kidney stone disease is an important cause of suffering and sick leave among workers in western countries. A large survey in a Swedish health screening programme gave cumulative incidence of kidney stones of $8.9 \%$ in men and $3.2 \%$ in women. ${ }^{10}$ The yearly incidence increased during the 1960 s and 70 s and has been estimated to be about $1 \%$ among men and $0.4 \%$ among women. Similar prevalence and incidence figures have been reported from investigations carried out in Norway, Denmark, and the United States. ${ }^{11}$ Age, family history, ${ }^{12-14}$ and nutritional factors ${ }^{14}$ have been suggested as aetiological factors and several investigators have noted that hypercalciuria is another risk factor for renal stone disease. ${ }^{13}{ }^{15-16}$ Studies of occupational exposures that may be associated with an increased prevalence of kidney stones are few. A Japanese study ${ }^{17}$ reported a higher than average incidence of urolithiasis among miners and quarrymen, but no further attempt was made to establish any particular exposure responsible for the higher incidence of renal stones in these occupations. A Swedish investigation of solderers exposed to cadmium $^{9}$ reported that a history of renal stones was more common among workers with high urinary cadmium concentrations, but it was not possible to establish a dose-response relation because of the small study size. Early studies of Swedish battery workers have also suggested a correlation between exposure to cadmium and prevalence of kidney stones. ${ }^{18-19}$ The aim of this study was to further explore the incidence of renal stones in relation to exposure to cadmium in a cohort of Swedish battery workers and to examine dose-response relations.

Material and methods

The original study population consisted of 902 workers employed for at least one year in a Swedish 
battery factory between 1931 and 1982 . The follow up period started in 1931 and ended in 1990. At the time of the study 601 living and 275 deceased workers could be identified. The remaining 26 workers $(2.9 \%)$ were lost to follow up, mainly because of emigration. Next of kin could be traced for 267 of the 275 dead workers $(97 \cdot 1 \%)$. Thus a total of 868 workers were included in the study.

\section{EXPOSURE}

The employment period(s) for each member of the study group was combined with measurements of cadmium in the air for different periods, giving a cumulative exposure estimate for each member of the study group. A subgroup with cumulative exposure of less than $250 \mu \mathrm{g} / \mathrm{m}^{3} \times$ years was used as an internal control group.

Cadmium in the blood and urine had been analysed since the end of the 1960s. Cumulative blood cadmium (nmole/1 $\times$ years), computed as mean blood cadmium times the number of years employed, and urinary cadmium (nmole/mmole creatinine) were used as internal dose estimates for some of the computations of dose-response relations between cadmium exposure and the risk of developing renal stones.

\section{DATA COLLECTION AND STATISTICS}

A postal questionnaire was sent to the 601 living workers and to the next of kin of the 267 deceased workers. The questionnaire included questions of exposure to hazardous substances, past and present health state, and smoking habits.

One question was Have you ever suffered from kidney disease? If yes, please state diagnosis (for example, kidney stone, urinary tract infection), the hospital, and date of admission. Validation of the diagnoses (through clinical signs, $x$ ray film examination, or surgery) was made from hospital records when feasible. Age standardised cumulative incidence with the whole group of male responders as standard population was computed for kidney stone disease, with the positive answers in the questionnaire as cases. The date of first admission to hospital was used as the date of onset of kidney stone disease (incidence date) and was recorded either from the questionnaire answer or from the date of diagnosis in the hospital records when available.

Person-years were computed for different age, calendar year, and exposure categories. ${ }^{20}$ Incidence rate ratios (IRRs) were computed by Poisson regression $^{21}$ for three cumulative exposure groups $(<250$, $250-<5000$, and $5000+\mu \mathrm{g} / \mathrm{m}^{3} \times$ years), standardised for calendar year in three groups, 1940-55, 1956-69 and 1970+), age (in three categories < 50, $50-69$, and $70+$ ), and smoking (in two categories, non-smokers and smokers). Smokers were defined as having smoked daily for at least a year.
Medians of biological monitoring data were computed for those who formed stones and those who did not. Wilcoxon's rank sum test was used for comparing these medians because of the skewed distribution of the biological data.

\section{Results}

The questionnaire was answered for 765 of the 868 study subjects $(88 \cdot 1 \%)$. Age, cumulative exposure, and biological data were similar among responders and non-responders as was the prevalence of tubular proteinuria. Only three of the 146 women $(2 \cdot 1 \%)$ reported kidney stones in the questionnaire and only male workers were included in the subsequent analyses.

Seventy four of the 619 male workers (or their relatives) $(12.0 \%)$ stated in the questionnaire that they had a history of kidney stones. Thirty five of these were verified in hospital records according to the questionnaire data. The hospital records for the remaining workers with positive answers to the question of unspecified urinary tract disease were then searched for possible histories of renal stones. A further 13 workers with kidney stone disease were then discovered. Thus a total of 87 male workers $(14 \cdot 1 \%)$ had a record of renal calculi, 48 of whom $(55.2 \%)$ could be verified in hospital records.

When the incidence data was compared with the company employment records, we found that 14 workers had renal stones that had appeared before the first date of hire. These were excluded from the analyses. For the remaining 73 workers, age standardised cumulative incidences were computed for four different exposure categories $(<250$, $250-<1500,1500-<5000$ and $5000+\mu \mathrm{g} / \mathrm{m}^{3} \times$ years) (figure). The solid line represents all 73 workers with a history of stones. The age standard-

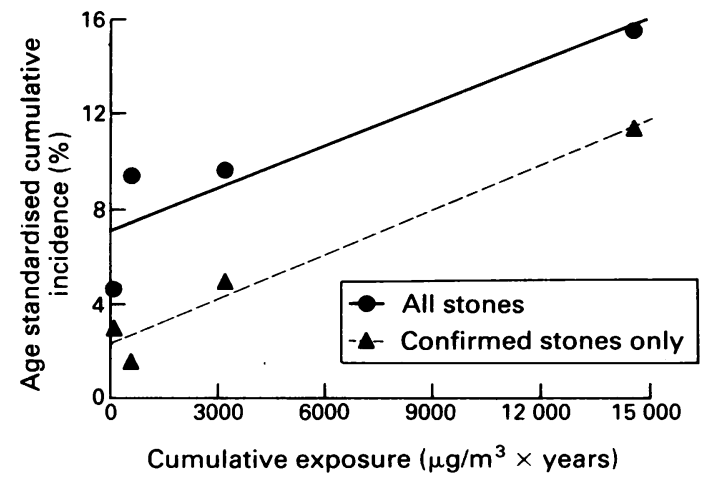

Age standardised cumulative incidence of urolithiasis in Swedish male battery workers exposed to cadmium. The solid line represents all workers with kidney stones; the dotted line includes only workers whose stones were confirmed in hospital records. 
Table 1 Incidence rate ratios (IRRs) for Swedish male battery workers exposed to cadmium

\begin{tabular}{llll}
\hline $\begin{array}{l}\text { Cumulative } \\
\text { exposure } \\
\left(\mu g / \mathrm{m}^{3} \times \text { years }\right)\end{array}$ & $\begin{array}{l}\text { No of stones/ } \\
\text { person-years }\end{array}$ & $\begin{array}{l}I R R_{1} \\
(95 \% C I)\end{array}$ & $\begin{array}{l}I R R_{2} \\
(95 \% \mathrm{CI})\end{array}$ \\
\hline$<250$ & $10 / 3201$ & $1 \cdot 0$ & $1 \cdot 0$ \\
$250-<5000$ & $29 / 7377$ & $1 \cdot 3(0 \cdot 6-2 \cdot 6)$ & $1 \cdot 6(0 \cdot 7-3 \cdot 4)$ \\
$\geqslant 5000$ & $34 / 5501$ & $2 \cdot 0(1 \cdot 0-4 \cdot 0)$ & $3 \cdot 0(1 \cdot 3-6 \cdot 8)$ \\
Test for trend: & & & $\mathrm{p}=0 \cdot 003$
\end{tabular}

Poisson regression. $\mathrm{IRR}_{1}=$ "crude" estimate, $\mathrm{IRR}_{2}=$ estimate standardised for age and calendar time.

ised cumulative incidence is plotted against the means in the selected cumulative exposure intervals. The dotted line includes only workers with renal calculi verified in hospital records (41 patients).

The incidence rate ratios (IRRs) are shown in table 1. Calendar year and age contributed significantly to the regression equation, but adding smoking category did not change the equation and the smoking term was therefore excluded.

When only workers with $\beta_{2}$ microglobulinuria ( $\geqslant 34 \mu \mathrm{g} / \mathrm{mmole}$ creatinine) were included in the analyses, the rate ratios increased as shown in table 2. Cumulative exposure to cadmium $(p=0.02)$ and calendar time $(p=0.04)$ contributed significantly to the regression equation and were thus included in the analysis. Age was not included, as the regression did not converge because of the sparseness of data. For comparison table 2 also shows the results for workers without tubular proteinuria $\left(\beta_{2}\right.$ microglobulin $<34 \mu \mathrm{g} /$ mmole creatinine). $\beta_{2}$ Microglobulin measurements were available for 33 stone formers. Thirteen of these workers had tubular proteinuria, that is, a prevalence of $39 \%$.

We also computed the IRRs for kidney stone disease with cumulative blood cadmium as the dose estimate. Table 3 shows the results. There is a suggestion of a dose-response relation similar to that for cumulative exposure to cadmium in air. Table 4 shows IRRs with urinary cadmium as the dose estimate. There is no obvious dose-response relation, even if workers with tubular proteinuria are excluded.
Table 3 Incidence rate ratios (IRRs) standardised for age and calendar time for Swedish male battery workers exposed to cadmium with cumulative blood cadmium as the dose estimate

\begin{tabular}{llll}
\hline $\begin{array}{l}\text { Cumulative } \\
\text { exposure } \\
\text { (nmolell } \times \text { years) }\end{array}$ & $\begin{array}{l}\text { No of stones/ } \\
\text { person-years }\end{array}$ & IRR & $(95 \%$ CI) \\
\hline$<400$ & $10 / 2969$ & 1.0 & \\
$400-<2500$ & $19 / 4188$ & 1.4 & $(0 \cdot 6-3 \cdot 0)$ \\
$\geqslant 2500$ & $11 / 1115$ & $\begin{array}{l}3.2 \\
(1 \cdot 3-8 \cdot 3)\end{array}$ \\
Test for trend: & & $\mathrm{p}=0.02$ & \\
\hline
\end{tabular}

Poisson regression.

Table 5 shows the median values of the biological data for those forming stones and those not. There are statistically significant differences between the two groups for all the biological data, but not for age.

\section{Discussion}

Urolithiasis was recognised in antiquity and despite changes in nutrition and living conditions there has been little change in the composition of kidney stones, which consist of uric acid, calcium oxalate, and various phosphates. There is considerable variation in the incidence of kidney stone disease both geographically and between different ages. The explanations for these variations are still unknown. The incidence of renal calculi seems to have increased in many western countries during the 1960 s and 70s. Thus a doubling of the rates over a 25 year period was reported from the United States ${ }^{11}$ and similar figures have been reported from other countries including Sweden. ${ }^{10}$

It has been claimed that climate is important for formation of kidney stones, possibly due to raised production of vitamin $D$ in the skin after exposure to sun light. ${ }^{22}$ Dietary factors, such as animal protein, fat, fibre, and alcohol, have been extensively discussed as potential causes for urolithiasis. ${ }^{14}$ There is, however, still no firm evidence to confirm these hypotheses. Occupational patterns have changed dramatically during the past decades, but few studies have tried to analyse the importance of occupational exposure for the development of renal calculi.

In general, it seems as if labourers have a lower

Table 2 Incidence rate ratios (IRRs) standardised for calendar time for Swedish male battery workers exposed to cadmium

\begin{tabular}{|c|c|c|c|c|}
\hline $\begin{array}{l}\text { Cumulative exposure } \\
\left(\mu g / m^{3} \times \text { years }\right)\end{array}$ & $\begin{array}{l}\text { No of stones/ } \\
\text { person-years }\end{array}$ & $I R R_{1}(95 \% C I)$ & $\begin{array}{l}\text { No of stones/ } \\
\text { person-years }\end{array}$ & $I R R_{2}(95 \% C I)$ \\
\hline $\begin{array}{l}<250 \\
250-<5000 \\
\geqslant 5000 \\
\text { Test for trend: }\end{array}$ & $\begin{array}{l}1 / 1522 \\
5 / 2976 \\
7 / 1181\end{array}$ & $\begin{aligned} & 1.0 \\
& 1.5(0.2-13.8) \\
& 4.4(0.5-39.9) \\
\mathrm{p}= & 0.05\end{aligned}$ & $\begin{array}{l}5 / 1572 \\
9 / 2456 \\
6 / 961\end{array}$ & $\begin{aligned} & 1 \cdot 0 \\
& 1 \cdot 2(0 \cdot 4-3 \cdot 6) \\
& 2 \cdot 1(0 \cdot 6-7 \cdot 3) \\
\mathrm{p}= & 0 \cdot 26\end{aligned}$ \\
\hline
\end{tabular}

$\mathrm{IRR}_{1}=$ only workers with $\beta_{2}$ microglobulin $\geqslant 34 \mu \mathrm{g} /$ mmole creatinine included; $\mathrm{IRR}_{2}=$ only workers with $\beta_{2}$ microglobulin $<34$ $\mu \mathrm{g} / \mathrm{mmole}$ creatinine included; Poisson regression. 
Table 4 Incidence rate ratios (IRRs) standardised for calendar time for Swedish male battery workers exposed to cadmium with urinary cadmium as the dose estimate

\begin{tabular}{lclll}
\hline $\begin{array}{l}\text { Cadmium in urine } \\
\text { (nmole/mmole creatinine) }\end{array}$ & $\begin{array}{l}\text { No of stones/ } \\
\text { person-years }\end{array}$ & IRR, (95\% CI) & $\begin{array}{l}\text { No of stones/ } \\
\text { person-years }\end{array}$ & IRR $(95 \%$ CI) \\
\hline$<1$ & $7 / 1372$ & $1 \cdot 0$ & $6 / 1294$ & $1 \cdot 0$ \\
$1-<5$ & $13 / 2886$ & $0 \cdot 8(0 \cdot 3-2 \cdot 0)$ & $7 / 2649$ & $0 \cdot 6(0 \cdot 2-1 \cdot 7)$ \\
$\geqslant 5$ & $14 / 1789$ & $1 \cdot 3(0 \cdot 5-3 \cdot 3)$ & $7 / 899$ & $1 \cdot 6(0 \cdot 5-5 \cdot 0)$ \\
Test for trend: & & $\mathrm{p}=0.45$ & & $\mathrm{p}=0 \cdot 39$
\end{tabular}

$\overline{\mathrm{IRR}_{1}}=$ all workers with laboratory data included. IRR $\mathrm{IR}_{1}=$ only workers with $\beta_{2}$ microglobulin $<34 \mu \mathrm{g} / \mathrm{mmole}$ creatinine included; Poisson regression.

incidence of stones than white collar workers. ${ }^{23} \mathrm{~A}$ recent Japanese study confirms this, but also reports a high prevalence among miners and quarrymen. ${ }^{17}$ Some studies have shown that occupational exposure to cadmium may be associated with a high prevalence of kidney stones. ${ }^{7-9} 18-19$ This study strengthens these earlier findings in showing a dose-response relation between exposure to cadmium and incidence of renal stones.

Several investigators have reported that incidence rates based on patients in hospital grossly underestimate the real incidence. ${ }^{1024}$ In a renal stone epidemiology study in Minnesota, it was concluded that up to $51 \%$ of patients with the diagnosis of urolithiasis were not admitted to hospital. ${ }^{11}$ Swedish investigators have reported that the reliability of information about kidney stone disease obtained through questionnaires is acceptable. ${ }^{25}$ When validating our questionnaire data against hospital records we were able to verify $55 \%$ of the self reported kidney stones, which is in agreement with the findings from the survey studies. The exclusion of those renal calculi that were not validated through hospital records resulted in a similar dose-response relation for the age adjusted cumulative incidence rates, with almost parallel regression lines as shown in the figure. Furthermore it seems reasonable to assume that specificity of self reported kidney stones is high because of the typical clinical picture. It is thus unlikely that a reported kidney stone has been mistaken for some other disease. There are probably carriers of kidney stones without symptoms, but an under-reporting of stones giving a low sensitivity would affect the relative risk only marginally. It therefore seemed reasonable to include all stones in the further analyses.
The figure shows cumulative incidence rates ranging from $4.6 \%$ to $15 \cdot 4 \%$ in the different exposure categories. If self reported kidney stones appearing before exposure started were also included, a total cumulative incidence of $12.0 \%$ was obtained, which corresponds well to figures derived from the general population, for instance, a large study in the Stockholm region reported a cumulative incidence of $8.9 \%$ in males. ${ }^{10}$

In the initial Poison regression analyses, including all study members, age, and calendar time contributed to the regression equation at the $95 \%$ significance level $(p=0.05, p=0.03)$. Both terms were thus included, giving an increased rate ratio compared with the crude rate ratio (only including the cumulative exposure terms), indicated a negative confounding for age and calendar time. This is contradictory to the observations of other investigators that the incidence of kidney stones for males has increased during the past decades; in the Minnesota study a doubling of the incidence rates was reported. ${ }^{11}$ Addition of a smoking term did not change the regression coefficients so not surprisingly smoking did not effect the risk of developing urolithiasis.

When only workers with tubular proteinuria ( $\beta_{2}$ microglobulin $>34 \mu \mathrm{g} / \mathrm{mmole}$ creatinine) were included the IRRs rose steeply. Because of the small numbers the confidence limits are wide, but the finding is nevertheless interesting, because earlier studies have indicated both a decrease ${ }^{26}$ and an increase $^{9}$ in prevalence of stones in workers exposed to cadmium and with proteinuria. Our finding is in agreement with other studies that have found an increased prevalence of tubular proteinuria among those forming kidney stones, ${ }^{27-29}$ two

Table 5 Comparisons of medians for biological data between battery workers exposed to cadmium who formed kidney stones and those who did not

\begin{tabular}{|c|c|c|c|c|c|}
\hline & No & Age & $\begin{array}{l}\text { Blood cadmium } \\
\text { (nmole/l) }\end{array}$ & $\begin{array}{l}\text { Urinary cadmium } \\
\text { (nmolelmmole } \\
\text { creatinine) }\end{array}$ & $\begin{array}{l}\text { Urinary microglobulin } \\
(\mu g / \text { mmole } \\
\text { creatinine })\end{array}$ \\
\hline $\begin{array}{l}\text { Those forming stones } \\
\text { Those not forming stones } \\
\text { p Value }\end{array}$ & $\begin{array}{r}73 \\
532\end{array}$ & $\begin{array}{l}67(61-69) \\
64(62-66) \\
0 \cdot 21\end{array}$ & $\begin{array}{l}63 \cdot 5(51 \cdot 6-95 \cdot 3) \\
50 \cdot 5(44 \cdot 5-55 \cdot 6) \\
0.02\end{array}$ & $\begin{array}{l}3 \cdot 7(2 \cdot 4-6 \cdot 4) \\
2 \cdot 0(1 \cdot 5-2 \cdot 5) \\
0 \cdot 008\end{array}$ & $\begin{array}{l}17 \cdot 6(9 \cdot 3-140) \\
6 \cdot 9(6 \cdot 4-7 \cdot 6) \\
0 \cdot 0007\end{array}$ \\
\hline
\end{tabular}

95\% CIs in parentheses. 
studies reporting a $13 \%$ prevalence of $\beta_{2}$ microglobulinuria in formers of renal calcium stones. ${ }^{27-28}$ We have previously reported that cumulative blood cadmium may be used as an internal dose estimate for long-term exposure to cadmium. ${ }^{30}$ When we used this dose estimate in the regression, the IRRs were similar to the rate ratios estimated from cumulative exposure to cadmium in work room air. Nevertheless, as tubular proteinuria is more common among those who form stones, our previous findings may be used for an early detection of those with a higher risk of developing tubular proteinuria and urolithiasis.

Urinary cadmium seems to be a less sensitive dose estimate, giving rise to a weaker dose response relation that did not change when workers with tubular proteinuria were excluded. This may seem surprising in view of the fact that urinary cadmium generally is assumed to reflect body burden. Also, tubular damage induced by cadmium is known to cause an increased urinary excretion of cadmium. If the urinary excretion of cadmium has been increased for a long period of time, however, it may eventually result in a lower kidney burden of cadmium and a decreasing concentration of urinary cadmium. Therefore cadmium in urine is not always a good dose indicator. Another possible explanation for the lack of a dose-response relation in the group of non-proteinuric workers is a random misclassification of subjects between the dose groups leading to a bias in the relative risk towards unity.

All biological data showed, however, statistically significant differences between those forming kidney stones and workers without kidney stones (table 5), thus indicating both higher internal cadmium doses and a greater degree of tubular damage among those forming stones.

In conclusion this study confirms earlier reports of a higher prevalence of kidney stones among workers exposed to cadmium. Furthermore, our results strengthen the earlier findings in showing a dose-response relation between exposure to cadmium and the risk for urolithiasis. The results thus indicate that renal calculi are a clinically important consequence of renal damage induced by cadmium. Urolithiasis commonly occurs together with tubular proteinuria.

1 Friberg L, Elinder CG, Kjellström T, Nordberg GF. Cadmium and health: a toxicological and epidemiological appraisal. Vol II. Boca Raton, Florida:CRC Press, 1986.

2 Lauwerys RR, Roels HA, Buchet JP, Bernard A, Stanescu D. Investigations on the lung and kidney function in workers exposed to cadmium. Environ Health Perspect 1979;28 $137-45$.

3 Piscator M. Long-term observations on tubular and glomerular function in cadmium-exposed persons. Environ Health Perspect 1984;54:175-9.

4 Mason HJ, Davison HJ, Wright, AG, et al. Relations between liver cadmium, cumulative exposure, and renal function in cadmium alloy workers. Br F Ind Med 1988;45:793-802.

5 Roels HA, Lauwerys RR, Buchet JP, Bernard AM, Vos A, Oversteyns $M$. Health significance of cadmium induced renal dysfunction: a five year follow up. $\mathrm{Br} \mathcal{F}$ Ind Med 1989;46:755-64.

6 Kido T, Nogawa K, Ishizaki M, et al. Long-term observation of serum creatinine and arterial blood $\mathrm{pH}$ in persons with cadmium-induced renal dysfunction. Arch Environ Health 1990;45:35-41.

7 Kazantzis G. Cadmium nephropathy. Contrib Nephrol 1979; 16:161-6.

8 Scott R, Cunningham C, McLelland A, Fell GS, FitzgeraldFinch OP, McKellar N. The importance of cadmium as a factor in calcified upper urinary tract stone disease-a prospective 7 year study. Brf Urol 1982;54:584-9.

9 Elinder CG, Edling C, Lindberg E, Kågedal B, Vesterberg O. Assessment of renal function in workers previously exposed to cadmium. $\mathrm{Br}$ F Ind Med 1985;42:754-60.

10 Ljunghall S, Christensson T, Wengle B. Prevalence and incidence of renal stone disease in a health screening programme. Scand f Urol Nephrol Suppl 1977;41:39-54.

11 Johnson CM, Wilson DM, O'Fallon WM, Malek RS, Kyrland LT. Renal stone epidemiology: a 25 year study in Rochester, Minnesota. Kidney Int 1979;16:624-31.

12 Borghi L, Ferretti PP, Elia GF, et al. Epidemiological study of urinary tract stones in a northern Italian city. $B r f$ Urol 1990;65:231-5.

13 Thun MJ, Schober S. Urolithiasis in Tennessee: an occupational window into a regional problem. Am $\mathcal{F}$ Public Health 1991;81:587-91.

14 Trinchieri A, Mandressi P, Luongo G, Pisani E. The influence of diet on urinary risk factors for stones in healthy subjects and idiopathic renal calcium stone formers. $\mathrm{Br} \mathcal{F}$ Urol 1991;67:230-6.

15 Lemann J, Worcester EM, Gray RW. Hypercalciuria and stones. Am f Kidney Dis 1991;4:386-91.

16 Nunziata V, Di Giovanni R, Lettera AM, Mancini M. Recurrent kidney stones: causes and diagnostic criteria in patients from Campania (southern Italy). Br f Urol 1991; 68:125-31.

17 Yoshida O, Okada Y. Epidemiology of Urolithiasis in Japan: A chronological and geographical study. Urol Int 1990;45: 104-11.

18 Friberg L. Health hazards in the manufacture of alkaline accumulators with special reference to ihronic cadmium poisoning (doctoral thesis). Stockholm: Karolinska Institute, 1950.

19 Ahlmark A, Axelsson B, Friberg L. Further investigations into kidney function and proteinuria in chronic cadmium poisoning. International Congress on Occupational Health 1961; 13:201-3.

20 Marsh GM, Preininger M. OCMAP: a user-oriented occupational cohort mortality analysis program. American Statistician 1980;34:245-6.

21 EGRET. User manual. Seattle: Statistics and Epidemiology Research Corporation 1988.

22 Better OS, Shabtai M, Kedar S, Melamud A, Berenheim J, Chaimovitz C. Increased incidence of nephrolithiasis $(N)$ in lifeguards (LG) in Israel. Adv Exp Med Biol 1980;128: $467-72$.

23 Ljunghall S. Environmental factors in the development of urolithiasis. Contrib Nephrol 1984;37:9-12.

24 Hiatt RA, Friedman GD. The frequency of kidney and urinary tract diseases in a defined population, Kidney Int 1982;22:63-8.

25 Ljunghall S, Hedstrand $\mathrm{H}$. Epidemiology of renal stones in a middle-aged male population. Acta Med Scand 1975; 197:439-45.

26 Adams RG, Harrison JF, Scott P. The development of cadmium-induced proteinuria, impaired renal function, and osteomalacia in alkaline battery workers. $Q \mathcal{F} \mathrm{Med} 1969$; 38:425-43.

27 Backman U, Danielson BG, Johansson G, Ljunghall S, Wikström B. Incidence and clinical importance of renal tubular defects in recurrent renal stone formers. Nephron 1980;25:96-101.

28 Wikström B, Backman U, Danielson BG, Fellström B, Johansson $G$, Ljunghall $S$. Tubular proteinuria in renal calcium stone formers. Ups $\mathcal{F}$ Med Sci 1985;90:25-30.

29 Kumar S, Sigmon D, Miller $T$, et al. A new model of nephrolithiasis involving tubular dysfunction/injury. $f$ Urol 1991;146:1384-9.

30 Järup L, Elinder CG, Spang G. Cumulative blood-cadmium and tubular proteinuria: a dose-response relationship. Int Arch Occup Environ Health 1988;60:223-9.

Accepted 7 September 1992 